\title{
Pengaruh Model Pembelajaran Think Pair Share terhadap Multiple Intelligence dan Hasil Belajar IPA
}

\author{
I. A. Anggia Pramesty Devi Ambaraputri1*, Ketut Pudjawan², I Gusti Ayu Tri \\ Agustiana $^{3}$
}

123 Jurusan Pendidikan Guru Sekolah Dasar, ${ }^{2}$ Teknologi Pendidikan, Universitas Pendidikan Ganesha, Singaraja, Indonesia

\begin{abstract}
Abstrak
Populasi dalam penelitian ini yaitu seluruh kelas IV SD yang terdiri dari 5 kelas dalam 5 sekolah dasar dengan total keseluruhan siswanya sebanyak 126 siswa dengan jumalh sampel sebanyak 47 siswa. Penelitian ini bertujuan untuk mengetahui: 1) pengaruh yang signifikan model pembelajaran think pair share terhadap multiple intelligence siswa yang ada pada pelajaran IPA, 2) pengaruh yang signifikan model pembelajaran think pair share terhadap hasil belajar siswa pada pelajaran IPA, 3)

Kata Kunci:

Hasil Belajar IPA, Multiple Intelligence, Model Pembelajaran Think Pair Share pengaruh yang signifikan model pembelajaran think pair share terhadap multiple intelligence dan hasil belajar siswa pada pelajaran IPA. Jenis penelitian ini adalah eksperimen semu dengan desain penelitian yaitu Non Equivalent Posttest Only Control Group Design. Populasi penelitian ini adalah seluruh siswa kelas IV Gugus X Kecamatan Buleleng. Sampel ditentukan dengan tenik random sampling. Teknik pengumpulan data menggunakan teknik tes berupa tes pilihan ganda dalam mengukur hasil belajar IPA dan non tes berupa angket untuk mengukur multiple intelligence siswa. Teknik analisis data menggunakan MANOVA (Mulitivariat Analysis of Variance). Hasil penelitian menunjukkan bahwa: Pertama, terdapat pengaruh yang signifikan model pembelajaran think pair share terhadap terhadap multiple intelligence siswa yang ada pada pelajaran IPA. Kedua, terdapat pengaruh yang signifikan model pembelajaran think pair share terhadap hasil belajar siswa pada pelajaran IPA. Ketiga, terdapat pengaruh model pembelajaran think pair share terhadap multiple intelligence dan hasil belajar siswa pada pelajaran IPA.
\end{abstract}

\begin{abstract}
The population in this study were all grade IV elementary schools consisting of 5 classes in 5 elementary schools with a total of 126 students with a total sample of 47 students. This study aims to find out: 1) a significant influence on think pair share learning models on multiple intelligence students who have in science lessons, 2) a significant influence on think pair share learning models on student learning outcomes in science lessons, 3) a significant effect of models Think pair share learning towards multiple intelligence and student learning outcomes in science lessons. This type of research is a quasi-experimental research design that is Non Equivalent Posttest Only Control Group Design. The population of this research is all students of class IV Cluster X Buleleng District. The sample is determined by random sampling technique. Data collection techniques using test techniques in the form of multiple choice tests in measuring the learning outcomes of science and non-tests in the form of a questionnaire to measure multiple student intelligence. Data analysis techniques using MANOVA (Mulitivariat Analysis of Variance). The results showed that: First, there was a significant influence on think pair share learning models on the multiple intelligence of students in science. Second, there is a significant influence of think pair share learning models on student learning outcomes in science lessons. Third, there is the effect of think pair share learning models on multiple intelligence and student learning outcomes in science lessons.
\end{abstract}

\footnotetext{
* Corresponding author. 


\section{PENDAHULUAN}

Berdasarkan bunyi UU. No. 20 Tahun 2003, pendidikan masih diyakini sebagai wadah dalam membentuk sumber daya manusia yang diharapkan. Melihat begitu pentingnya pendidikan dalam pembentukan sumber daya manusia, maka peningkatan mutu proses pendidikan merupakan hal yang wajib dilakukan bersama-sama secara berkesinambungan guna mengikuti perubahan zaman yang terjadi. Salah satu faktor yang mempengaruhi peningkatan mutu pendidikan adalah peningkatan mutu proses pembelajaran di dalam kelas. Salah satu upaya tenaga pendidik dalam meningkatkan mutu proses pembelajaran adalah dengan menggunakan dan menerapkan strategi, model, metode, dan menggunakan media pembelajaran yang tentunya akan membuat siswa lebih mudah memahami materi yang akan dibelajarkan guru.

Proses pembelajaran di kelas seharusnya dapat mencapai tujuan pembelajaran, salah satunya adalah tujuan pembelajaran IPA di sekolah dasar. Tujuan pembelajaran IPA di sekolah dasar yaitu untuk membuat siswa memahami tentang alam sekitar dan bagaimana cara melestarikannya, selain itu siswa juga diharapkan mampu menggunakan dan menerapkan sikap ilmiah dalam memecahkan suatu permasalahan. Namun, pada kenyataannya menurut (Hasan, M., Yarmi, G., 2018) mengungkapkan hasil tes dan survey PISA tahun 2015 yang melibatkan 540.000 siswa di 70 negara, performa siswa-siswi Indonesia masih tergolong rendah. Rata-rata skor pencapaian siswa-siswi Indonesia untuk sains, membaca, dan matematika berada di peringkat 62, 61, dan 63 dari 69 negara yang dievaluasi. Peringkat dan rata-rata skor Indonesia tersebut tidak berbeda jauh dengan hasil tes dan survey PISA terdahulu pada tahun 2012 yang juga berada pada kelompok penguasaan materi yang rendah.

Hal ini juga terungkap dari hasil wawancara, observasi, dan studi dokumen yang telah dilakukan di Gugus X Kecamatan Buleleng yang dilakukan dari tanggal 24 Oktober - 1 November 2019 didapatkan beberapa permasalahan yang ditemui. Berdasarkan hasil wawancara, siswa kurang aktif dalam mengikuti proses pembelajaran. Selain itu, selama melakukan observasi terhadap guru di sekolah ditemukan beberapa kendala yaitu model pembelajaran yang digunakan di dalam pembelajaran khususnya IPA kurang inovatif sehingga membuat siswa bosan dan mempengaruhi hasil belajar IPA. Kurangnya partisipasi dan interaksi di dalam proses pembelajaran. Masih banyak tenaga pendidik yang masih lebih fokus pada hasil belajar yang diperoleh siswa daripada proses dan keterampilan lain yang muncul dalam diri siswa. Selain itu, pembelajaran yang diberikan oleh guru kurang dikaitkan dengan kehidupan seharihari sehingga membuat siswa masih kesulitan memahami materi yang dibelajarkan oleh guru. Berikut data hasil belajar IPA siswa kelas IV di SDN Gugus X Kecamatan Buleleng Kabupaten Buleleng yang telah diterima. Hasil tersebut dapat dilihat pada Tabel 1 di bawah ini.

Tabel 1. Data Hasil Belajar Siswa Kelas IV SD Gugus X Kecamatan Buleleng

\begin{tabular}{|c|c|c|c|c|c|c|c|}
\hline \multirow[t]{2}{*}{ No. } & \multirow[t]{2}{*}{ Nama Sekolah } & \multirow{2}{*}{$\begin{array}{l}\text { Jumlah } \\
\text { Siswa }\end{array}$} & \multirow[t]{2}{*}{ KKM } & \multicolumn{2}{|c|}{$\begin{array}{c}\text { Jumlah Siswa } \\
\text { Tuntas }\end{array}$} & \multicolumn{2}{|c|}{$\begin{array}{c}\text { Jumlah Siswa Tidak } \\
\text { Tuntas }\end{array}$} \\
\hline & & & & Siswa & $\%$ & Siswa & $\%$ \\
\hline 1. & SDN 1 Kaliuntu & 27 & 65 & 5 & $18,52 \%$ & 22 & $81,48 \%$ \\
\hline 2. & SDN 2 Kaliuntu & 15 & 75 & 5 & $33,33 \%$ & 10 & $66,67 \%$ \\
\hline 3. & SDN 3 Kaliuntu & 20 & 65 & 5 & $25,00 \%$ & 15 & $75,00 \%$ \\
\hline 4. & SDN 4 Kaliuntu & 32 & 70 & 8 & $25,00 \%$ & 24 & $75,00 \%$ \\
\hline 5. & SD Katolik Karya & 32 & 70 & 9 & $28,13 \%$ & 23 & $71,87 \%$ \\
\hline & Total & 126 & - & 32 & $25,00 \%$ & 94 & $75,00 \%$ \\
\hline
\end{tabular}

Dari Tabel 1. di atas, menunjukkan bahwa hasil belajar siswa 75\% masih di bawah KKM (Kriteria Ketuntasan Minimal). Hal ini merupakan suatu masalah yang tentunya harus diatasi. Sehingga untuk mengatasi masalah tersebut menggunakan model think pair share (TPS) untuk dapat mengembangkan multiple intelligence dan meningkatkan hasil belajar IPA. Model think pair share (TPS) akan membuat siswa memahami situasi permasalahan, dapat berpartisipasi dan berinteraksi, menerima pendapat orang lain, dan mencapai tujuan pembelajaran secara bersama-sama. Model ini juga tidak hanya memfokuskan pada apa yang dihasilkan siswa melainkan juga pada bagaimana proses yang dilalui siswa.

Model pembelajaran think pair share (TPS) dirancang untuk mempengaruhi pola interaksi siswa di dalam proses pembelajaran (dalam(Trianto, 2012)). Selain itu, menurut (Zulkarnain, I., \& Djamilah, 2015) model pembelajaran kooperatif tipe think pair share (TPS) adalah suatu model pembelajaran dimana dalam proses pembelajarannya siswa dituntut untuk aktif memikirkan pemecahan masalah (thinking), berdiskusi memecahkan masalah (pairing), dan memprensentasikan/memaparkan hasil pemecahan masalah (sharing). Menurut (Sutarminingsih, N. P. E., Arcana I N., \& Sudiana, 2013) dalam 
model pembelajaran think pair share (TPS) siswa diberi kesempatan untuk bekerja sendiri dan akan bekerja sama dengan pasangannya. Setelah siswa mencari pasangannya, guru akan membimbing jalannya diskusi sehingga tercipta suasana belajar yang aktif, kreatif, dan menyenangkan. Selain itu, guru juga dapat memotivasi siswa untuk belajar dan saling membantu pasangannya. Dalam model pembelajaran think pair share (TPS) guru berperan sebagai motivator, fasilitator, mediator, dan evaluator. Sedangkan siswa memiliki peran aktif dalam proses pembelajaran di kelas (dalam(Kusuma, F. W., \& Aisyah, 2012)). Jadi dapat disimpulkan, model pembelajaran think pair share (TPS) ialah model pembelajaran yang mengatur pola diskusi di dalam kelas dan memberikan kesempatan kepada siswa untuk lebih banyak melakukan interaksi dan menumbuhkan partisipasi.

Multiple intelligence merupakan 8 kecerdasan yang dimiliki setiap individu. Menurut (Sunartini, 2013), pada dasarnya multiple intelligence merupakan pengembangan dari kecerdasan otak (IQ), kecerdasan emosional (EQ), dan kecerdasan spiritual (SQ).Selama ini kecerdasan hanya menitikberatkan pada kemampuan aritmatis, logis, dan verbal. Kecerdasan manusia jauh lebih luas dan tidak bersifat 1 dimensi saja, sehingga tidak akan cukup jika hanya dihitung menggunakan tes, melainkan bisa juga dinilai dengan melakukan observasi. Multiple intelligence mencangkup 8 kecerdasan diantaranya adalah kecerdasan linguistik, kecerdasan matematis-logis, kecerdasan spasial, kecerdasan kinestis-jasmani (kecerdasan kinestik-tubuh), kecerdasan musikal (kecerdasan musik), kecerdasan interpersonal, kecerdasan intrapersonal, dan kecerdasan naturalis (Riyanto, 2009). Menurut (Sunartini, 2013) terdapat bbeberapa faktor yang mempengaruhi multiple intelligence yaitu faktor bawaan, faktor minat, faktor lingkungan, faktor kematangan, dan faktor kebebasan. Hasil belajar merupakan tolak ukur yang digunakan guru untuk mengetahui pemahaman siswa terhadap materi yang telah dibelajarkan. (Susanti, 2018) menyatakan bahwa hasil belajar yaitu kemampuan-kemampuan yang diperoleh siswa setelah kegiatan pembelajaran yang mencakup aspek kognitif, afektif dan psikomotorik yang sesuai dengan tujuan pembelajaran. Menurut Anni (dalam Nurroeni, 2013), hasil belajar merupakan sebuah perubahan perilaku yang diperoleh pembelajar setelah mengalami aktivitas belajar. Salah satunya dalam mata pelajaran IPA. Menurut Slameto (dalam(Trisnadewi, K. A., Darsana I W. \& Wiyasa, 2014)) hasil belajar yang diperoleh siswa tidak terlepas dari faktor-faktor yang mempengaruhi yaitu faktor internal dan faktor eksternal. IPA merupakan salah satu mata pelajaran wajib yang dibelajarkan di sekolah. Menurut (Abdan, 2016) Ilmu Pengetahuan Alam (IPA) adalah pengetahuan yang dapat diperoleh melalui pengumpulan data dengan eksperimen, pengamatan, dan deduksi untuk dapat menghasilkan suatu penjelasan tentang sebuah gejala yang dapat dipercaya. Dengan adanya mata pelajaran IPA akan membuat siswa lebih memahami alam di sekitarnya. Pemahaman tersebut akan memberikan siswa pengetahuan untuk menjaga dan merawat alam di sekitar mereka. (Agustiana, 2014) menyatakan bahwa "Ilmu Pengetahuan Alam (IPA) adalah salah satu aspek pendidikan dengan menggunakan IPA sebagai alat untuk mencapai tujuan pendidikan, khususnya pendidikan IPA". (Kariani, N. K., Putra, K. N. S., \& Ardana, 2014) menyatakan bahwa "perubahan-perubahan serta kemampuan yang diperoleh seseorang setelah mengalami proses belajar khususnya proses belajar IPA".

Berdasarkan permasalahan yang diuraikan di atas maka akan dilakukan penelitian eksperimen dengan judul "Pengaruh Model Pembelajaran Think Pair Share Terhadap Multiple Intelligence dan Hasil Belajar IPA Siswa Kelas IV SD Gugus X Kecamatan Buleleng Tahun Pelajaran 2019/2020".

\section{METODE PENELITIAN}

Penelitian ini menggunakan rancangan penelitian kuantitatif dengan jenis penelitiannya yaitu eksperimen semu (quasy exsperiment). Penelitian ini menggunakan rancangan non equivalent posttest only control group design (Mahendra, 2019). Bagan dalam penelitian ini terdapat pada Tabel 2. yakni sebagai berikut.

Tabel 2. Rancangan Penelitian

\begin{tabular}{lccc}
\hline & Kelas & Treatment & Post-test \\
\hline Eksperimen & $\mathrm{X}$ & $\mathrm{O}_{1}$ \\
Kontrol & - & $\mathrm{O}_{2}$ \\
\hline
\end{tabular}

Populasi dalam penelitian ini yaitu seluruh kelas IV SD Gugus X Kecamatan Buleleng yang terdiri dari 5 kelas dalam 5 sekolah dasar dengan total keseluruhan siswanya sebanyak 126 siswa. Sebelum penentuan sampel, seluruh kelas IV SD Gugus X Kecamatan Buleleng dilakukan uji kesetaraan dengan menggunakan nilai UTS muatan IPA dengan menggunakan analisis ANAVA A. Berdasarkan perhitungan ANAVA A, F hitung sebesar 1,21 dan F tabel 2,44 dengan taraf signifikansi 5\%. Maka $F_{\text {hitung }}<F_{\text {tabel }}$ dengan 
taraf signifikansi 5\% ini berarti $\mathrm{H}_{0}$ diterima dan $\mathrm{H}_{1}$ ditolak, dengan demikian tidak terdapat perbedaan yang signifikan hasil tes awal mengenai pengetahuan IPA siswa kelas IV SD di Gugus X Kecamatan Buleleng. Hal ini berarti, setiap anggota populasi yakni seluruh kelas IV SD di Gugus X Kecamatan Buleleng adalah setara atau homogen.

Populasi yang dinyatakan telah setara, dapat dilanjutkan dengan menentukan sampel

penelitian. Teknik pengambilan sampel yang digunakan adalah random sampling. Pengacakan sampel ini dipilih melalui kelas yang dipilih tidak ada campur tangan dari peneliti dan setiap kelasnya memiliki peluang yang sama. Masing-masing kelas IV di SD yang ada pada Gugus X Kecamatan Buleleng Kabupaten Buleleng ditulis di atas kertas dan digulung. Kemudian diambil 2 gulungan. Setelah itu, dari 2 gulungan tersebut dipilih lagi gulungan pertama untuk menjadi kelas eksperimen dan gulungan kedua menjadi kelas kontrol.

Penelitian ini memiliki dua variabel yang terdiri dari variabel bebas dan variabel terikat. Variabel bebasnya yaitu model pembelajaran think pair share, sedangkan variabel terikatnya yaitu multiple intelligence dan hasil belajar IPA. Teknik pengumpulan data yang digunakan yaitu tes pilihan ganda untuk mengukur hasil belajar IPA dan non tes berupa kuisioner untuk mengukur multiple intelligence siswa. Materi pelajaran yang digunakan adalah TEMA 7 yaitu indahnya keragaman di negeriku.

Sebelum instrumen digunakan, perlu dilakukan pengujian instrumen dengan 4 uji yaitu uji pakar dari hasil perhitungan diperoleh 40 butir pernyataan untuk instrumen multiple intelligence yang dapat digunakan hanya 35 butir pernyataan, sedangkan instrumen hasil belajar IPA diperoleh 35 butir soal yang dapat digunakan hanya 30 butir soal. Pada uji validitas menggunakan formula KR-21 (Mahendra, 2019) diperoleh dari 40 butir pernyataan dapat digunakan 35 butir saja, untuk butir nomor 6, 17, 22, 26, dan 28 dinyatakan tidak valid, sedangkan hasil belajar IPA, 30 butir soal dinyatakan valid. Uji reliabilitas pada multiple intelligence berada pada kategori reliabilitas tinggi karena hasil perhitungan yang didapat 0,7973, sedangkan untuk instrumen hasil belajar IPA berada pada kategori reliabilitas sangat tinggi karena hasil perhitungan yang didapat 0,83. Uji taraf kesukaran tes hasil belajar, diperoleh 1 soal berada pada kategori sukar, 16 soal berada pada kategori sedang, dan 13 soal berada pada kategori mudah. Uji daya beda tes hasil belajar, diperoleh 7 soal kategori cukup baik, 20 soal kategori baik, dan 3 soal kategori sangat baik. Jadi, dapat disimpulkan bahwa pada instrumen multiple intelligence yang dapat digunakan hanya 40 butir pernyataan, sedangkan pada hasil belajar IPA yang dapat digunakan hanya 30 butir soal.

Analisis data dilakukan dengan menggunakan analisis deskriptif dan analisis inferensial dengan bantuan SPSS Statistics 17 for Windows. Analisis deskriptif terdiri dari mean, median, standar deviasi, varians, range, skor minimum, dan skor maksimum. Analisis inferensial terdiri dari uji prasyarat dan uji hipotesis. Uji prasyarat dianalisis menggunakan 3 tahapan yaitu uji normalitas sebaran data, uji homogenitas varians, dan uji korelasi antar variabel terikat. Uji normalitas sebaran data menggunakan analisis Kolmogorof-Smirnov dan Shapiro-Walk untuk meyakinkan bahwa populasi tersebut berdistrbusi normal, sehingga uji hipotesis dapat dilakukan. Uji homogenitas dilakukan dengan analisis Box's M dan Levene's Test yang dilakukan pada pasangan kelas eksperimen dan kelas kontrol. Apabila data telah homogen maka analisis MANOVA bisa dilanjutkan. Uji korelasi antar variabel terikat dilakukan untuk mengetahui korelasi atau hubungan antar variabel multiple intelligence dengan hasil belajar IPA di kelas IV pada kelas eksperimen dan kelas kontrol.

Teknik pengumpulan data menggunakan teknik tes berupa pilihan ganda dalam mengukur hasil IPA dan non tes berupa angket untuk mengukur multiple intelligence siswa. Teknik analisis data untuk menguji hipotesis menggunakan analisis MANOVA ((Mulitivariat Analysis of Variance) dengan bantuan SPSS Statistics 17 for Windows dengan taraf signifikansi 5\% (0,05). Terdapat tiga hipotesis pada penelitian ini yaitu hipotesis I menyatakan bahwa terdapat pengaruh model pembelajaran think pair share terhadap multiple intelligence siswa kelas IV di SD Gugus X Kecamatan Buleleng tahun pelajaran 2019/2020, Hipotesis II menyatakan bahwa terdapat pengaruh model pembelajaran think pair share terhadap hasil belajar IPA siswa kelas IV di SD Gugus X Kecamatan Buleleng tahun pelajaran 2019/2020, dan Hipotesis III menyatakan bahwa terdapat pengaruh model pembelajaran think pair share terhadap multiple intelligence dan hasil belajar IPA siswa kelas IV di SD. Gugus X Kecamatan Buleleng tahun pelajaran 2019/2020. 


\section{ANALISIS DAN PEMBAHASAN}

Deskripsi data pada penelitian ini terdiri dari 4 yatu pada Tabel 3.

Tabel 3. Rekapitulasi Statistik Deskriptif Variabel Penelitian

\begin{tabular}{lcccc}
\hline \multirow{2}{*}{ Statistik } & \multicolumn{2}{c}{ Kelas Eksperimen } & \multicolumn{2}{c}{ Kelas Kontrol } \\
\cline { 2 - 5 } & $\begin{array}{c}\text { Multiple } \\
\text { Intelligence }\end{array}$ & $\begin{array}{c}\text { Hasil Belajar Bahasa } \\
\text { Indonesia }\end{array}$ & $\begin{array}{c}\text { Multiple } \\
\text { Intelligence }\end{array}$ & $\begin{array}{c}\text { Hasil Belajar Bahasa } \\
\text { Indonesia }\end{array}$ \\
\hline$N$ & 20 & 20 & 27 & 27 \\
Mean & 159,70 & 26,30 & 138,00 & 18,67 \\
Median & 162,00 & 26,50 & 140,00 & 19,00 \\
Varians & 99,48 & 4,74 & 180,61 & 2,23 \\
Standar Deviasi & 9,97 & 2,17 & 13,43 & 1,49 \\
Range & 35 & 8 & 54 & 7 \\
Minimum & 140 & 21 & 110 & 15 \\
Maksimum & 175 & 29 & 164 & 22 \\
\hline
\end{tabular}

Berdasarkan Tabel 3, untuk mengetahui skor multiple intelligence siswa data di kelas eksperimen terlebih dahulu dihitung rata-rata ideal (Mi) dan standar ideal (SDi). $\mathrm{M}_{\mathrm{i}}=1 / 2$ (skor maksimal + skor minimal $)=1 / 2(175+140)=157,5$ dan $\mathrm{SD}_{\mathrm{i}}=1 / 6(175-140)=5,83$. Jadi, dapat disimpulkan bahwa skor rata-rata multiple intelligence siswa di kelas eksperimen termasuk dalam kategori "Sedang".

Data variabel multiple intelligence di dalam kelas kontrol, untuk mengetahui skor multiple intelligence siswa terlebih dahulu dihitung rata-rata ideal (Mi) dan standar ideal (SDi). $\mathrm{M}_{\mathrm{i}}=1 / 2$ (skor maksimal + skor minimal) $=1 / 2(164+110)=137$ dan $\mathrm{SD}_{\mathrm{i}}=1 / 6($ skor maksimal - skor minimal $)=1 / 6$ $(164-110)=9$. Jadi, dapat disimpulkan bahwa skor rata-rata multiple intelligence di kelas kontrol termasuk pada kategori "Sedang".

Selanjutnya pada data variabel hasil belajar IPA di kelas eksperimen, untuk mengetahui skor hasil belajar IPA siswa terlebih dahulu dihitung rata-rata ideal (Mi) dan standar ideal (SDi). $\mathrm{M}_{\mathrm{i}}=1 / 2$ (skor maksimal + skor minimal $)=1 / 2(29+21)=25$ dan $\mathrm{SD}_{\mathrm{i}}=1 / 6($ skor maksimal - skor minimal $)=1 / 6(29-$ $21)=1,33$. Jadi, dapat disimpulkan bahwa skor rata-rata hasil belajar IPA di kelas eksperimen termasuk pada kategori "Tinggi". Pada data data variabel hasil belajar IPA di kelas kontrol, untuk mengetahui skor hasil belajar IPA siswa terlebih dahulu dihitung rata-rata ideal (Mi) dan standar ideal (SDi). $\mathrm{M}_{\mathrm{i}}=1 / 2$ (skor maksimal + skor minimal) $=1 / 2(22+15)=18,5$ dan $\mathrm{SD}_{\mathrm{i}}=1 / 6($ skor maksimal - skor minimal $)=1 / 6(22-$ $15)=1,16$. Jadi, dapat disimpulkan bahwa skor rata-rata hasil belajar IPA di kelas kontrol termasuk pada kategori "Sedang".

Selain analisis deskriptif, juga digunakan analisis inferensial. Penjelasannya sebagai berikut.

\section{A. Uji Prasyarat}

1. Uji Normalitas Sebaran Data

Uji normalitas sebaran data dilakukan unuk membuktikan bahwa data sampel yang berasal dari populasi tersebut telah normal. Uji ini dilakukan dengan bantuan program SPSS 17 dor windows dengan dengan perhitungan Kolmogorof-Smirnov. Data yang berdistribusi normal apabila signifikansi > 0,05 (taraf signifikansi 5\%). Berikut ini rekapitulasi hasil dari uji normalitas sebaran data pada Tabel 4.

Tabel 4. Rekapitulasi Hasil Uji Normalitas Sebaran Data

\begin{tabular}{llllllll}
\hline \multirow{2}{*}{ Kelompok } & \multirow{2}{*}{ Variabel } & \multicolumn{2}{c}{ Kolmogorov-Smirnov } & \multicolumn{3}{c}{ Shapiro-Wilk } \\
\cline { 3 - 8 } & & Statistik & Df & Sig. & Statistik & Df & Sig. \\
\hline \multirow{2}{*}{ Eksperimen } & Multiple Intelligence & 0,157 & 20 & 0,200 & 0,912 & 20 & 0,069 \\
& Hasil Belajar IPA & 0,137 & 20 & 0,200 & 0,927 & 20 & 0,138 \\
\multirow{3}{*}{ Kontrol } & Multiple Intelligence & 0,164 & 20 & 0,161 & 0,865 & 20 & 0,010 \\
& Hasil Belajar IPA & 0,163 & 20 & 0,173 & 0,836 & 20 & 0,003 \\
\hline
\end{tabular}

Berdasarkan data pada Tabel 4, nilai pada statistik Kolmogorov-Smirnov pada data statistik skor multiple intelligence siswa di kelompok eksperimen dan kontrol adalah 0,141 dan 0,098 dengan nilai 
signifikansi sebesar 0,200 dan 0,200. Data statistik skor hasil belajar IPA kelompok eksperimen dan kontrol adalah 0,145 dan 0,185 dengan nilai signifikansi sebesar 0,200 dan 0,071. Jadi, dapat disimpulkan bahwa keempat kelompok data tersebut telah berdistribusi normal karena nilai signifikansinya lebih besar dari 0,05.

\section{Uji Homogenitas Varian}

Uji homogenitas varians dilakukan pada pasangan kelas eksperien dan kelas kontrol. Uji ini dilakukan dengan bantuan program SPSS 17 for Windows menggunakan uji Box's M dan Levene's Test. Berikut ini hasil perhitungan uji homogenitas varians pada multiple intelligence dan hasil belajar IPA di kelas eksperimen dan kelas kontrol yang disajikan pada Tabel 5.

Tabel 5. Rekapitulasi Hasil Pengujian Uji Homogenitas Varians Pada Uji Box's M dan Levene's Test

\begin{tabular}{|c|c|c|c|c|}
\hline & Levene Statistic & df1 & df2 & Sig. \\
\hline Multiple Intelligence & 1,094 & 1 & 45 & 0,301 \\
\hline Hasil Belajar IPA & 2,962 & 1 & 45 & 0,092 \\
\hline \multicolumn{5}{|c|}{ Box's Test of Equality of Covariance Matrices ${ }^{a}$} \\
\hline \multicolumn{2}{|c|}{ Box's M } & \multicolumn{3}{|c|}{5,689} \\
\hline \multicolumn{2}{|c|}{$\mathrm{F}$} & \multicolumn{3}{|c|}{1,802} \\
\hline \multicolumn{2}{|c|}{ df1 } & \multicolumn{3}{|c|}{3} \\
\hline \multicolumn{2}{|c|}{ df2 } & \multicolumn{3}{|c|}{168801,410} \\
\hline \multicolumn{2}{|c|}{ Sig. } & \multicolumn{3}{|c|}{0,144} \\
\hline
\end{tabular}

Berdasarkan Tabel 5. hasil analisis menunjukkan bahwa keseluruhan nilai signifikansi dari perhitungan uji Box's M dan Levene's Test lebih besar dari 0,05. Nilai Levene's Test untuk multiple intelligence dan hasil belajar IPA sebesar 1,094 dan 2,962 dengan singnifikansi 0,301 dan 0,092. Nilai Box's M sebesar 5,689 dengan signifikansi 0,144. Jadi, dapat disimpulkan bahwa data (1) multiple intelligence siswa kelas eksperimen dan kelas kontrol, (2) hasil belajar IPA siswa kelas eksperimen dan kelas kontrol memiliki varian yang homogen serta analisis MANOVA dapat dilanjutkan.

3. Uji Korelasi antar Variabel Terikat

Uji korelasi antar variabel terikat dilakukan untuk mengetahui korelasi atau hubungan antar variabel multiple intelligence dengan hasil belajar IPA di kelas eksperimen dan kelas kontrol. Berikut ini dapat dilihat pada Tabel 6 .

Tabel 6. Hasil Uji Korelasi antar Variabel Terikat di Kelas Eksperimen

\begin{tabular}{lccc}
\hline & & $\begin{array}{c}\text { Multiple } \\
\text { Intelligence }\end{array}$ & Hasil Belajar IPA \\
\hline \multirow{3}{*}{ Multiple Intelligence } & Pearson Correlation & 1 & $-0,083$ \\
& Sig. (2-tailed) & & 0,681 \\
Hasil Belajar IPA & $N$ & 20 & 20 \\
& Pearson Correlation & $-0,083$ & 1 \\
& Sig. (2-tailed) & 0,681 & 20 \\
\hline
\end{tabular}

Berdasarkan Tabel 6, dapat diketahui bahwa korelasi antara multiple intelligence dan hasil belajar IPA di kelas eksperimen memiliki nilai signifikansi sebesar 0,681 lebih besar dari 0,05. Jadi, dapat disimpulkan bahwa multiple intelligence dan hasil belajar IPA di kelas eksperimen tidak berkorelasi.

Tabel 7. Hasil Uji Korelasi antar Variabel Terikat di Kelas Kontrol

\begin{tabular}{|c|c|c|c|}
\hline & & $\begin{array}{c}\text { Multiple } \\
\text { Intelligence }\end{array}$ & Hasil Belajar IPA \\
\hline \multirow{3}{*}{ Multiple Intelligence } & Pearson Correlation & 1 & 0,291 \\
\hline & Sig. (2-tailed) & & 0,140 \\
\hline & $N$ & 27 & 27 \\
\hline
\end{tabular}




\begin{tabular}{|c|c|c|c|}
\hline & & $\begin{array}{c}\text { Multiple } \\
\text { Intelligence }\end{array}$ & Hasil Belajar IPA \\
\hline \multirow{3}{*}{ Hasil Belajar IPA } & Pearson Correlation & 0,291 & 1 \\
\hline & Sig. (2-tailed) & 0,140 & \\
\hline & $N$ & 27 & 27 \\
\hline
\end{tabular}

Berdasarkan Tabel 7, dapat diketahui bahwa korelasi antara multiple intelligence dan hasil belajar IPA di kelas kontrol memiliki nilai signifikansi sebesar 0,140 lebih besar dari 0,05. Jadi, dapat disimpulkan bahwa multiple intelligence dan hasil belajar IPA di kelas kontrol tidak berkorelasi.

Berdasarkan hasil uji prasyarat seperti uji normalitas sebaran data, homogenitas varians, dan korelasi antar variabel terikat dapat disimpulkan bahwa data yang dipakai pada penelitian ini dapat diteruskan untuk dipakai dalam pengujian hipotesis.

\section{B. Pengujian Hipotesis}

Hipotesis I menyatakan bahwa terdapat pengaruh model pembelajaran think pair share terhadap multiple intelligence siswa kelas IV di SD Gugus X Kecamatan Buleleng tahun pelajaran 2019/2020. Pengujian pada hipotesis I menggunakan MANOVA melalui statistik F varians. Kriteria pengujiannya yaitu jika nlai $\mathrm{F}$ dengan taraf signifikansi kurang dari 0,05 maka hipotesis nol ditolak $\left(\mathrm{H}_{0}\right)$ dan menerima hiptesis alternatif $\left(\mathrm{H}_{1}\right)$. Uji hipotesis I disajikan pada Tabel 8 berikut.

Tabel 8. Hasil Uji Tests of Between-Subjects Effects

\begin{tabular}{|c|c|c|c|c|c|c|}
\hline Source & $\begin{array}{c}\text { Dependent } \\
\text { Variable }\end{array}$ & $\begin{array}{c}\text { Type III Sum } \\
\text { of Squares }\end{array}$ & $d \boldsymbol{f}$ & Mean Square & $\boldsymbol{F}$ & Sig. \\
\hline \multirow{2}{*}{$\begin{array}{l}\text { Corrected } \\
\text { Model }\end{array}$} & $\begin{array}{l}\text { Multiple } \\
\text { Intelligence }\end{array}$ & $5410,226^{c}$ & 1 & 5410,226 & 36,965 & 0,000 \\
\hline & $\begin{array}{l}\text { Hasil Belajar } \\
\text { IPA }\end{array}$ & $669,460^{a}$ & 1 & 669,460 & 203,277 & 0,000 \\
\hline \multirow{2}{*}{ Intercept } & $\begin{array}{l}\text { Multiple } \\
\text { Intelligence }\end{array}$ & 1018248,013 & 1 & 1018248,013 & 6957,147 & 0,000 \\
\hline & $\begin{array}{l}\text { Hasil Belajar } \\
\text { IPA }\end{array}$ & 23231,502 & 1 & 23231,502 & 7054,100 & 0,000 \\
\hline \multirow{2}{*}{ Kelas } & $\begin{array}{l}\text { Multiple } \\
\text { Intelligence }\end{array}$ & 5410,226 & 1 & 5410,226 & 36,965 & 0,000 \\
\hline & $\begin{array}{l}\text { Hasil Belajar } \\
\text { IPA }\end{array}$ & 669,460 & 1 & 669,460 & 203,277 & 0,000 \\
\hline \multirow{2}{*}{ Error } & $\begin{array}{l}\text { Multiple } \\
\text { Intelligence }\end{array}$ & 6586,200 & 45 & 146,360 & & \\
\hline & $\begin{array}{l}\text { Hasil Belajar } \\
\text { IPA }\end{array}$ & 148,200 & 45 & 3.293 & & \\
\hline \multirow{2}{*}{ Total } & $\begin{array}{l}\text { Multiple } \\
\text { Intelligence }\end{array}$ & 1030856,000 & 47 & & & \\
\hline & $\begin{array}{l}\text { Hasil Belajar } \\
\text { IPA }\end{array}$ & 23390,000 & 47 & & & \\
\hline \multirow{2}{*}{$\begin{array}{l}\text { Corrected } \\
\text { Total }\end{array}$} & $\begin{array}{l}\text { Multiple } \\
\text { Intelligence }\end{array}$ & 11996,426 & 46 & & & \\
\hline & $\begin{array}{l}\text { Hasil Belajar } \\
\text { IPA }\end{array}$ & 817,660 & 46 & & & \\
\hline
\end{tabular}

Berdasarkan Tabel 8, maka diketahui bahwa nilai F Pillae Trace, Wilk Lambda, Hotteling Trace, dan Roy's Largest Root seluruhnya memiliki signifikansi 0,000. Jika diterapkan taraf siginifikansi $\alpha=0,05$, maka nilai signifikansi lebih kecil dari pada $\alpha$ sehingga $\mathrm{F}$ signifikan. Hal ini berarti hipotesis nol $\left(\mathrm{H}_{0}\right)$ ditolak dan hipotesis alternatif $\left(\mathrm{H}_{1}\right)$ diterima. Jadi, dapat disimpulkan bahwa terdapat pengaruh yang signifikan model pembelajaran think pair share terhadap multiple intelligence dan hasil belajar IPA siswa kelas IV di SD Gugus X Kecamatan Buleleng tahun pelajaran 2019/2020. 
Hasil uji pada hipotesis I, kelas eksperimen memperoleh skor rata-rata 159,70 dan kelas kontrol memiliki skor rata-rata 138,55. Hal ini menunjukkan bahwa skor rata-rata multiple intelligence siswa di kelas eksperimen lebih tinggi daripada di kelas kontrol. Berdasarkan hasil pengujian menggunakan MANOVA melalui statistik F varians diketahui bahwa nilai $F$ sebesar 36,965 dengan signifikansi 0,000. Maka, hipotesis nol $\left(\mathrm{H}_{0}\right)$ ditolak dan hipotesis alternatif $\left(\mathrm{H}_{1}\right)$ diterima. Hal ini berarti terdapat pengaruh yang signifikan model pembelajaran think pair share terhadap multiple intelligence siswa kelas IV di SD Gugus X Kecamatan Buleleng tahun pelajaran 2019/2020.

Berdasarkan data hasil analisis tersebut, dapat dikatakan bahwa penggunaan model pembelajaran think pair share mampu membuat multiple intelligence siswa lebih baik. Hal itu tercermin pada pelaksanaan pembelajaran dengan model pembelajaran think pair share memberikan pengalaman dan wawasan yang lebih luas kepada siswa untuk memiliki serta mengasah keterampilan multiple intelligence yang ada pada dirinya.

Temuan dalam penelitian ini sejalan dengan hasil penelitian yang telah dilakukan dan diperkuat oleh Halijah pada tahun 2017 menyatakan bahwa hasil proses belajar setelah penelitian sudah dapat meningkatkan kemampuan berbahasa Indonesia dengan menerapkan model pembelajaran think pair share (TPS).

Hasil uji pada hipotesis II, kelas eksperimen memperoleh skor rata-rata 26,30 dan kelas kontrol memiliki skor tara-rata 18,65. Hal ini menunjukkan bahwa skor rata-rata hasil belajar IPA siswa di kelas eksperimen lebih tinggi dari pada di kelas kontrol. Pada hasil pengujian menggunakan MANOVA melalui statistik F varians diketahui bahwa nilai F sebesar 203,277 dengan signifikansi 0,000 sehingga dapat dinyatakan bahwa nilai signifikansi lebih kecil dari pada 0,05 sehingga F signifikan. Maka, hipotesis nol $\left(\mathrm{H}_{0}\right)$ ditolak dan hipotesis alternatif $\left(\mathrm{H}_{1}\right)$ diterima. Hal ini berarti terdapat pengaruh yang signifikan model pembelajaran think pair share terhadap hasil belajar IPA siswa kelas IV di SD Gugus X Kecamatan Buleleng tahun pelajaran 2019/2020.

Berdasarkan data hasil analisis tersebut, dapat dikatakan bahwa penggunaan model pembelajaran think pair share lebih baik untuk meningkatkan hasil belajar IPA siswa. Hal itu tercermin pada pelaksanaan pembelajaran dengan model pembelajaran think pair share terhadap muatan materi IPA terdapat tiga tahap. Tahap pertama yaitu siswa akan diberikan waktu untuk berpikir sendiri jawaban dari masalah yang dihadapi atau masalah yang diberikan. Tahap kedua siswa akan berpasang-pasangan untuk menyatukan jawaban dirinya sendiri dengan pasangannya. Tahap ketiga siswa akan membagikan jawaban dirinya dengan pasangannya kepada seluruh temannya. Dengan demikian, perbedaan hasil belajar IPA siswa dapat dilihat dari hasil pembelajaran yang dilaksanakan pada kedua kelompok siswa tersebut, kelompok siswa yang mengikuti model pembelajaran think pair share dengan kelompok siswa yang tidak mengikuti model pembelajaran think pair share.

Hasil penelitian ini sejalan dengan penelitian yang dilakukan oleh Ita Rosita pada tahun 2015 menyatakan bahwa dengan menerapkan pembelajaran kooperatif tipe think pair share, siswa yang awalnya memiliki keterampilan kerja sama yang rendah, akan termotivasi untuk meningkatkan kerja sama dan kolaborasi.

Hasil uji pada hipotesis III, hasil analisis data multiple intelligence dan hasil belajar IPA menunjukkan bahwa terdapat perbedaan multiple intelligence dan hasil belajar IPA siswa di kelas eksperimen dengan di kelas kontrol. Hal ini bisa dilihat dari MANOVA yang telah dilakukan.

Berdasarkan uji MANOVA diperoleh hasil nilai F Pillae Trace, Wilk Lambda, Hotteling Trace, dan Roy's Largest Root seluruhnya memiliki signifikansi 0,000. Jika nilai signifikansi lebih kecil dari 0,05 maka F signifikan. Hal ini berarti hipotesis nol $\left(\mathrm{H}_{0}\right)$ ditolak dan hipotesis alternatif $\left(\mathrm{H}_{1}\right)$ diterima. Jadi, dapat disimpulkan bahwa terdapat pengaruh yang signifikan model pembelajaran think pair share terhadap multiple intelligence dan hasil belajar IPA siswa kelas IV di SD Gugus X Kecamatan Buleleng tahun pelajaran 2019/2020.

Berdasarkan data hasil analisis tersebut, dapat dikatakan bahwa penggunaan model pembelajaran think pair share terhadap multiple intelligence dan hasil belajar IPA siswa. Hal itu tercermin pada pelaksanaan pembelajaran dengan model pembelajaran think pair share memberikan siswa lebih banyak pengalaman dan kesempatan yang lebih luas untuk dapat mengembangkan keterampilan dalam mengkonstruksikan sebuah permasalahan. Selain itu, model pembelajaran think pair share terdapat tiga tahap. Tahap pertama yaitu siswa akan diberikan waktu untuk berpikir sendiri jawaban dari masalah yang dihadapi atau masalah yang diberikan. Tahap kedua siswa akan berpasang-pasangan untuk menyatukan jawaban dirinya sendiri dengan pasangannya. Tahap ketiga siswa akan membagikan jawaban dirinya dengan pasangannya kepada seluruh temannya. Dengan demikian, perbedaan keterampilan multiple intelligence dan hasil belajar IPA dapat dilihat dari hasil pembelajaran yang dilaksanakan pada kedua kelompok tersebut, siswa yang mengikuti model pembelajaran think pair share memiliki hasil yang lebih tinggi dibandingkan dengan siswa yang tidak mengikuti model pembelajaran think pair share. 
Hasil penelitian ini sejalan dengan penelitian yang telah dilakukan oleh Ariantini, N. K. A., Rati, N. W., \& Murda, I N., pada tahun 2017 menyatakan bahwa terdapat perbedaan yang signifikan hasil belajar IPA antara siswa yang mengikuti pembelajaran dengan model pembelajaran kooperatif Tipe TPS berbantuan media visual dan kelompok siswa yang mengikuti pembelajaran yang berpusat pada guru.

\section{KESIMPULAN}

Berdasarkan hasil dari penelitian yang telah dipaparkan di bab sebelumnya, maka dapat disimpulkan bahwa model pembelajaran think pair share (TPS) berpengaruh terhadap multiple intelligence dan hasil belajar IPA siswa kelas IV SD Gugus X Kecamatan Buleleng Tahun Pelajaran $2019 / 2020$.

Selain itu penelitian ini diharapkan dapat dijadikan acuan dalam pemilihan model pembelajaran inovatif yang sesuai dengan Kurikulum 2013 dengan melihat karakteristik muatan pembelajaran yang terintegrasi, pendekatan saintifik serta sesuai dengan kebutuhan siswa. Kegiatan pembelajaran di dalam kelas akan menjadi lebih inovatif dan variatif karena dapat menggunakan dan menerapkan model pembelajaran yang sesuai Kurikulum 2013. Salah satu model pembelajaran yang dapat disarankan, yaitu model pembelajaran think pair share, terutama untuk kegiatan pembelajaran IPA. Dengan begitu, siswa diaharapkan akan lebih aktif, bertanggung jawab, membentuk interaksi yang positif antar siswa dalam mengikuti proses pembelajaran serta mampu membangun pengetahuannya sendiri untuk mencapai hasil belajar yang lebih optimal, khususnya pada keterampilan multiple intelligence dan hasil belajar IPA.Selain itu, peneliti lain agar mampu menemukan model pembelajaran yang lebih inovatif dan bervariasi yang sesuai dengan Kurikulum 2013 agar dapat memotivasi siswa untuk mengikuti kegiatan pembelajaran dengan baik dan memperoleh hasil yang lebih optimal.

\section{DAFTAR PUSTAKA}

Abdan. (2016). Meningkatkan Hasil Belajar IPA Konsep Cahaya Melalui Pembelajaran ScienceEdutainment Berbantuan Media Animasi. Jurnal Kreatif Online, 4.

Agustiana, I. G. A. T. (2014). Konsep Dasar IPA Aspek Biologi. Penerbit Ombak.

Hasan, M., Yarmi, G., \& S. (2018). Pengaruh Integrasi Pembelajaran Literasi Dan Kemampuan Berpikir Kritis Terhadap Keterampilan Menulis Paragraf Siswa Sekolah. Jurnal Prosiding Seminar Dan Diskusi Pendidikan Dasar.

Kariani, N. K., Putra, K. N. S., \& Ardana, I. K. (2014). Model Problem Based Learning Menggunakan Metode Probing-Prompting Berpengaruh Terhadap Hasil Belajar Ipa Siswa. MIMBAR PGSD Undiksha, 2.

Kusuma, F. W., \& Aisyah, M. N. (2012). Implementasi Model Pembelajaran Kooperatif Tipe think pair share untuk meningkatkan aktivitas belajar akuntansi siswa kelas XI IPS 1 SMA Negeri 2 Wonosari tahun ajaran 2011/2012. Jurnal Pendidikan Akuntansi Indonesia, 10.

Mahendra, I. W. E. (2019). Analisis Butir Soal. Workshop Peningkatan Kompetensi Evaluasi Pembelajaran Guru SLB N 1 Buleleng.

Riyanto, Y. H. (2009). . Paradigma Baru Pembelajaran. Kencana.

Sunartini, F. V. (2013). Menggali Kemampuan Akademik Peserta Didik Melalui Aplikasi Multiple Intelegensi Dalam Proses Pembelajaran. Jurnal Humanika, 13.

Susanti, P. D. A. (2018). Peningkatan Hasil Belajar IPA Melalui Penerapan Model Pembelajaran Berbasis Masalah (Problem Based Learning) pada Siswa Kelas V SDN Purwasari III Kabupaten Karawang. Jurnal Prosiding Seminar Dan Diskusi Nasional Pendidikan Dasar.

Sutarminingsih, N. P. E., Arcana I N., \& Sudiana, I. W. (2013). Pengaruh Model Pembelajaran Think Pair Share (TPS) Terhadap Hasil Belajar IPA Kelas V SD Negeri Kubutambahan Kecamatan Kubutambahan. MIMBAR PGSD Undiksha, 1. 
Trianto. (2012). Model Pembelajaran Terpadu. Bumi Aksara.

Trisnadewi, K. A., Darsana I W. \& Wiyasa, I. K. N. (2014). Penerapan Pembelajaran Inkuiri Berbantuan Media Audiovisual Untuk Meningkatkan Aktivitas dan Hasil Belajar IPS Siswa Kelas V SD No. 3 Tibubeneng, Kuta Utara, Badung. MIMBAR PGSD Undiksha, 2.

Zulkarnain, I., \& Djamilah, S. (2015). Penerapan Model Pembelajaran Think Pair Share Terhadap Kemampuan Pemahaman Matematis Siswa Sekolah Menengah Pertama. Jurnal Pendidikan Matematika, 3, 105-117. 